\title{
Essential Trace Elements and Arsenic in Thermal Springs, Afghanistan
}

\author{
Hussain Ali Jawadi ${ }^{1} \mathbb{D}$, Hasan Ali Malistani ${ }^{1}$, Mohammad Anvar Moheghy ${ }^{1}$ and Jay Sagin ${ }^{2,3, *(\mathbb{D})}$ \\ 1 Department of Geology, Faculty of Geosciences, Bamyan University, Bamyan City, Bamyan 1601, Afghanistan; \\ hussainali.jawadi@daad-alumni.de (H.A.J.); hmalistani@gmail.com (H.A.M.); Moheghy@gmail.com (M.A.M.) \\ 2 Department of Geosciences, Western Michigan University, Kalamazoo, MI 49008, USA \\ 3 The Environment \& Resource Efficiency Cluster (EREC), School of Engineering and Digital Sciences, \\ Nazarbayev University Research and Innovation System, Nazarbayev University, \\ Nur Sultan 010000, Kazakhstan \\ * Correspondence: zhanay.sagintayev@nu.edu.kz
}

check for updates

Citation: Jawadi, H.A.; Malistani, H.A.; Moheghy, M.A.; Sagin, J. Essential Trace Elements and Arsenic in Thermal Springs, Afghanistan. Water 2021, 13, 134. https://doi.org/ 10.3390/w13020134

Received: 8 December 2020 Accepted: 4 January 2021 Published: 8 January 2021

Publisher's Note: MDPI stays neutral with regard to jurisdictional clai$\mathrm{ms}$ in published maps and institutional affiliations.

Copyright: (C) 2021 by the authors. Licensee MDPI, Basel, Switzerland. This article is an open access article distributed under the terms and conditions of the Creative Commons Attribution (CC BY) license (https:// creativecommons.org/licenses/by/ $4.0 /)$.

\begin{abstract}
Thermal springs are natural hydrogeological features which are highly affected by local volcanism or tectonic activity. Thermal springs are the best source of hydrothermal energy to heat houses and aid in the recovery of skin diseases. However, they consist of some heavy and trace metals such as arsenic, lead, zinc, copper, iron, and so forth. Somehow, the thermal springs of central Bamyan have become contaminated with some essential trace elements. Thus, this study was conducted to assess and determine the number of these trace elements in the thermal springs. To achieve these objectives, a preliminary survey, water sampling, and in situ measurements of physicochemical parameters were conducted in research areas. All the collected water samples were analyzed chemically to determine the amount of trace elements, including arsenic, barium, copper, iron, manganese, and zinc. The study shows that temperature ranged from 16 to $32{ }^{\circ} \mathrm{C}$, while the average $\mathrm{pH}$ value was 6.25 . Almost all of the trace elements showed an extremely high value of electrical conductivity (average: $5713 \mu \mathrm{S} / \mathrm{cm}$ ) and significantly high total dissolved solids (average: $3063 \mathrm{mg} / \mathrm{L}$ ). The average value of chloride was $797 \mathrm{mg} / \mathrm{L}$, which is dramatically higher than standard values. In regard to trace element concentration, almost all thermal springs were heavily contaminated with arsenic and it was recorded as $100 \mu \mathrm{g} / \mathrm{L}$ in the eastern part of central Bamyan. The average amounts of barium, copper, iron, manganese, and zinc were 4.14, 6.05, 1.90, 1.76 , and $0.74 \mathrm{mg} / \mathrm{L}$, respectively. In conclusion, the water of the thermal springs of central Bamyan are not suitable for human consumption because of the significant amount of trace elements as well as the high-water quality index value. Using these springs for drinking and irrigation purposes has been deemed inappropriate.
\end{abstract}

Keywords: thermal spring; trace element; arsenic; Bamyan; central Afghanistan; contamination

\section{Introduction}

Thermal springs are natural phenomena [1] and geological features which can be found in "active or semi active volcanic areas" [2] or observed in and around tectonic zones [1]. Generally, thermal springs have advantages and disadvantages for human and livestock use [3]. They act as the surface expression of underlying hydrothermal systems [2] and can be used for hydrothermal energy production. However, thermal water often presents anomalously high background values of different potentially toxic elements, which can present severe risks for human consumption. Due to lack of clean water resources, some consume it for drinking water [4,5], but most of the water is affected by high concentrations of arsenic [6] and other trace elements. Arsenic is also released through the thermal springs into the environment and surface/groundwater [4,7]. Contamination of groundwater through trace elements is a substantial concern for environmental health scientists since this water normally is required for human and animal consumption [8]. 
Research has shown that trace elements can be derived in groundwater from natural and anthropogenic sources [8].

Natural trace elements can cause health issues, even in low natural concentrations [9-13]. At the same time, there could be different local acclimation and adaption to the natural environment to existing trace concentrations. As [9] reported in a notable study, organisms in Norway adapted to relatively high trace elements such as $\mathrm{Pb}, \mathrm{Cu}, \mathrm{Zn}$, and $\mathrm{Mn}$, which could be toxic for the identical organisms in Poland. Another example is from Austria, where trace element counts for As (Arsenic) are 6-20 times higher than in other countries. However, As is bonded well naturally in As-geochemical deposits without creating health problems [9]. Proper field investigations and geomapping are very important before taking any action, including any clean-up or remediation activities [9]. Water-rock interactions are vital for thermal water chemistry studies and developing geothermal systems worldwide [14-22]. Determining the origin of thermal fluids is one the main tasks of these investigations [14].

Water resources, including thermal springs, have not been assessed in detail in Afghanistan to date, even though a range of thermal springs exist in different parts of the country. It will be helpful to carry out research on water-rock interactions and the origins of thermal water, similar to the hydrochemical studies developed by [15], in Afghanistan. Relatively recent research has focused on Afghanistan's river basins [23], creating an atlas of water for the country [24], a detailed analysis of hydrogeology of the Kabul Basin [25], evaluating groundwater availability in the Kabul Basin [26], establishing a conceptual model of groundwater resources in the Kabul Basin [27], and studying the inventory of groundwater resources in the Kabul Basin [28]. Furthermore, a preliminary study of geothermal energy including thermal springs around the country as well as thermal springs of Bamyan province was conducted by Saba et al. in 2004 [29]. This study revealed that active geothermal systems, which indicate thermal springs, are generally located in the main axis areas of the Hindu Kush running along the Herat faults. Utilization of thermal springs in Afghanistan might have begun with the settlement of the first people in the Hindu Kush valleys, [29] but since 1940, a number of thermal springs in Herat (Obe and Safed Koh), Balkh (Aabe Garm), and Orezgan provinces were developed for therapeutic purposes [29]. In 1964, an attempt was made by Soviet geologists who cooperated with the Geological Survey of Afghanistan (GSA) to conduct a systematic study on thermal waters around the country for their potential mineral content. Their study explored a number of hot springs in Kalu Valley (Ghorband, Shina, Dare-e Soof, and Istalef), some of which are observation points of the current study. [29]. It was found that thermal springs in Afghanistan are mainly bicarbonate, chloride, sulfate, and sodium chloride type [29,30]. It is important to note that a similar study of the anomalously high concentration of metals in thermal water was conducted in the Thriasion Plan (NW Attica, Greece) [31] and it showed that the total dissolved solids (TDS) ranged from 535 to $13567 \mathrm{mg} / \mathrm{L} \mathrm{Cl}^{-}: 17.7-7269.7 \mathrm{mg} / \mathrm{L}$, $\mathrm{SO}_{4}{ }^{2-}: 8.2-782 \mathrm{mg} / \mathrm{L}$, and $\mathrm{NO}_{3}{ }^{-}: 5.7-293 \mathrm{mg} / \mathrm{L}$. However, in central Bamyan thermal springs, the amount of $\mathrm{Cl}^{-}$ranged from 49 to $1630 \mathrm{mg} / \mathrm{L}, \mathrm{SO}_{4}{ }^{2-}: 64-1430 \mathrm{mg} / \mathrm{L}$, and $\mathrm{NO}_{3}{ }^{-}: 1.3-21 \mathrm{mg} / \mathrm{L}$.

Since knowledge of thermal water chemistry is still limited in Afghanistan, this work aimed to fill this knowledge gap. This aim was reached by (1) determining the contamination rate and protection strategies; (2) determining the arsenic and some trace element amounts in the thermal springs; (3) and assessing the vulnerability and health risks caused by arsenic and essential trace elements such as barium, copper, iron, manganese, and zinc. 


\section{Materials and Methods}

\subsection{Study Area}

\subsubsection{Location and Climate Condition}

Bamyan is located in the center of Afghanistan (Figure 1) within latitude $33^{\circ} 48^{\prime} \mathrm{N}$ to $35^{\circ} 28^{\prime} \mathrm{N}$ and longitude $66^{\circ} 24^{\prime} \mathrm{E}$ to $68^{\circ} 14^{\prime} \mathrm{E}$ [32]. The specific study area is situated in the central highland of Bamyan province between two main mountainous ranges: the Hindu Kush Mountains in the north and the Baba Mountain range in the south. Geographically, it is placed within longitude $67^{\circ} 20^{\prime} \mathrm{E}$ to $68^{\circ} 10^{\prime} \mathrm{E}$ and latitude $34^{\circ} 30^{\prime} \mathrm{S}$ to $35^{\circ} 10^{\prime} \mathrm{N}$ (Figure 1), and topographic elevation is around $2520 \mathrm{~m}$ above sea level. Kahmard and Saighan districts are located in the northern part, the Baba Mountain range in the south, the Shaikh Ali and Surkh Pars districts of Parwan province in the east, and the Yakawlang district in the western part of study area (Figure 1).

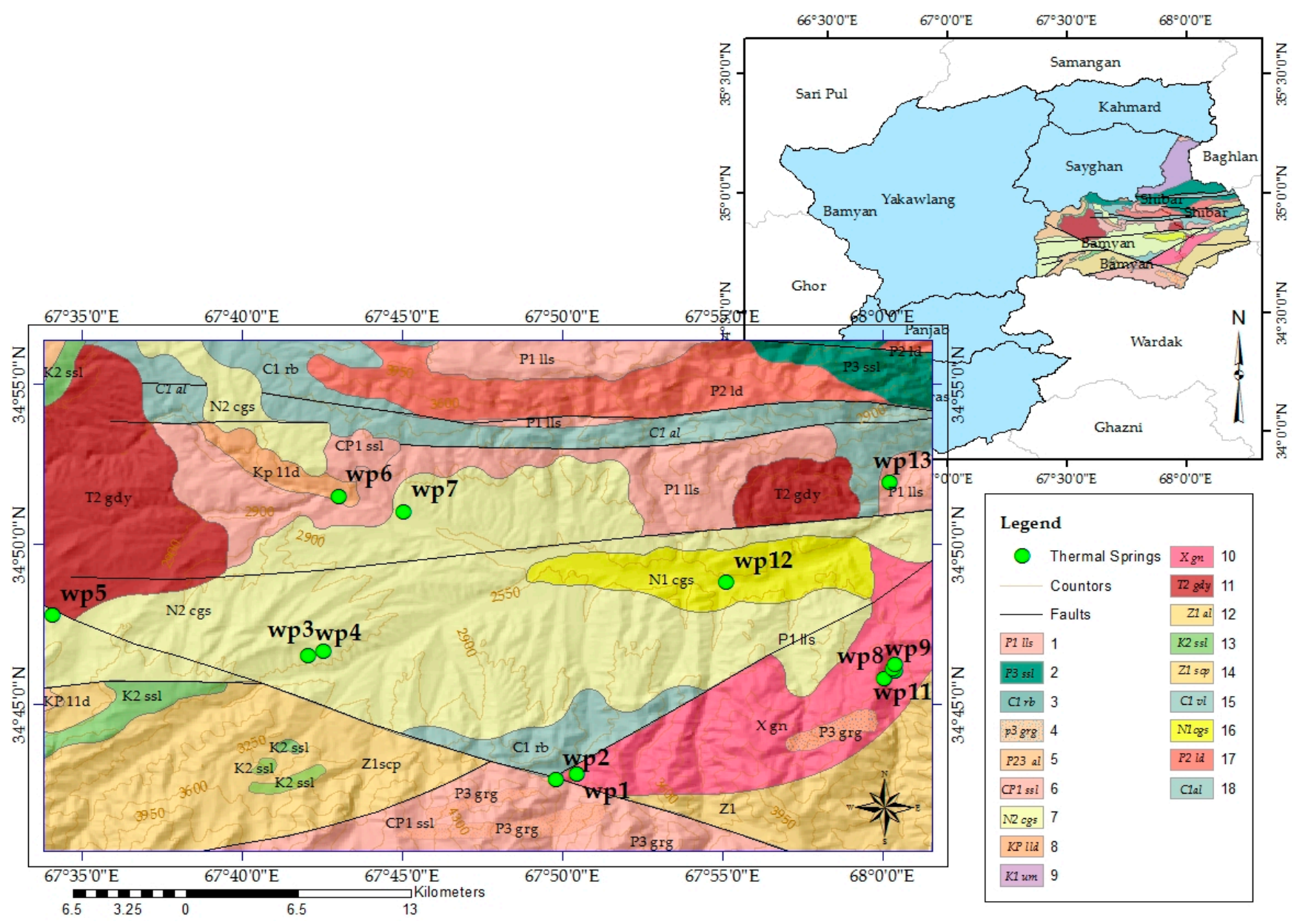

Figure 1. Geological map which isolated the geological setting of the study area from the entire Bamyan province. This map was created by the geographical information system (ArcGIS 10.2). In the legend: 1 . Sandstone and siltstone (Early Permian), 2. Sandstone and siltstone (Oligocene), 3. Lava (Carboniferous), 4. Granite and granodiorite (Oligocene), 5. Andesite lava (Oligocene), 6. Siltstone and sandstone (Early Permian), 7. Conglomerate and sandstone (Pliocene), 8. Limestone and dolomite (Late Permian), 9. Granodiorite and granite (Early Triassic), 10. Gneisses (Paleoproterozoic), 11. Granodiorite and granosyenite (Late Triassic), 12. Metavolcanic andesite lava (Early Neoproterozoic), 13. Sandstone and siltstone lava (Late Neoproterozoic), 14. Schist and rhyolite (Early Neoproterozoic), 15. Rhyolite and basalt (Early Carboniferous), 16. Conglomerate and sandstone (Miocene), 17. Limestone and dolomite (Paleocene), 18.Andesite Lava (Early Carboniferous). 
The climate of Bamyan varies significantly throughout the region from arid to semiarid, with warm summers and cold winters. During cold winters, the average temperature is $-5{ }^{\circ} \mathrm{C}$, while sometimes it can decrease to $-20{ }^{\circ} \mathrm{C}$ [33]. The average recorded precipitation is $165 \mathrm{~mm}$, which mainly occurs as snow [34].

\subsubsection{Geological Setting}

The geology of Bamyan valley, similar to many mountain chains around the world, consists of crystalline or metamorphic bedrock with different rock formations from the Paleoproterozoic to Quaternary periods [30]. Metamorphic and igneous rocks mainly exist in most parts of the southern hills and the Baba Mountain ridge. At higher elevations, granite to gabbro, schist, slate quartzite, and gneiss are major rock units in the southern ridges that are especially exposed [35].

Glacial and alluvial deposits of snow-glacier melting processes during the Quaternary period created hollows/cirques, huge moraines, and alluvial fans/plains that provide the major water reservoirs for Bamyan valley [30].

The northwestern Bamyan ridges (Figure 1) primarily have sedimentary rock formations comprised mostly of limestone and carbonates with an intercalation of basic to intermediate volcanic. Their ages vary from Carboniferous, to Permian, and to Cretaceous. Granitic batholiths of the northern Hindu Kush (Triassic-Jurassic) intrude the strata several times [35].

A deep east-west regional fault through Bamyan valley cuts all rock formations and channels into deep hydrothermal brines. Related hot springs and brines are widespread alongside the fault, especially in the eastern (Paymory Area) and western (Azhdar Area) sides of the city of Kabul (Figure 1).

\subsubsection{Hydrological Setting}

Bamyan is a mountainous region and the central part of this province is surrounded with two main mountains called the Baba Mountain, which is located at the southern part and prolongs from east to west, and the Hindu Kush Mountain, located at the northern part of central Bamyan and which prolongs almost parallel to the Baba Mountain. Central Bamyan is a wide valley located between the Hindu Kush Mountain range (north) and the Baba Mountain range (south). Many valleys and subvalleys connect these mountainous regions to the main Bamyan valley.

From a hydrological point of view, the main river of Bamyan flows from the main Bamyan valley (Figure 2). Almost all the southern valleys are wet during the year because the water from the rivers that flow through these valleys originates from Baba Mountain's glaciers and snow at high elevations and natural lakes. The main rivers which originate from Baba Mountain include the Foladi River, which has several subrivers: the Dokani River, the Darra Sadat River, the Darra Ahangaran River, and the Kalu River (Figure 2). Comparatively, the Hindu Kush Mountain provides less water than the Baba Mountain. Therefore, the majority of the valleys located in the northern part are dry except for some small flows which have water for a limited time during the year.

There are a variety of thermal hot and cold springs throughout central Bamyan, especially in the south, such as the Foladi, Dokani, Sadat, Agangaran, and Kalu valleys (Table 1). Further, some cold springs are situated in the Bamyan main valley, which supply the urban water systems. In some parts, these springs are used for irrigation and drinking. 


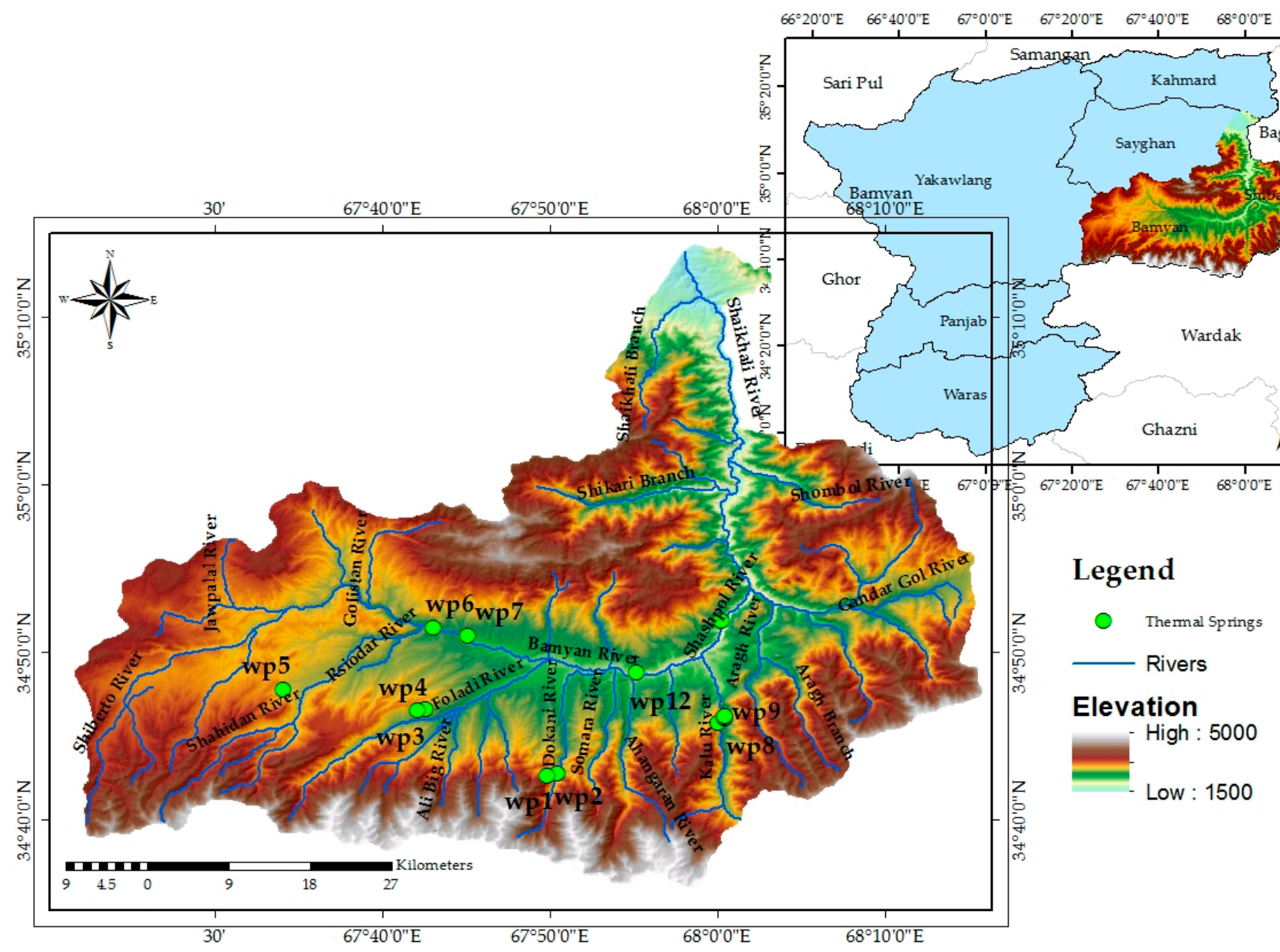

Figure 2. Hydrological map of study area. This map was created by the geographical information system (ArcGIS 10.2).

Table 1. Location of observation points (thermal springs).

\begin{tabular}{|c|c|c|c|c|c|}
\hline \multirow[t]{2}{*}{ Symbol } & \multirow[t]{2}{*}{ Location } & \multirow[t]{2}{*}{ Description of Location } & \multicolumn{2}{|c|}{$\begin{array}{l}\text { Coordinates } \\
\text { (WGS1984) }\end{array}$} & \multirow{2}{*}{$\begin{array}{c}\text { Elevation } \\
\text { (m) }\end{array}$} \\
\hline & & & Longitude & Latitude & \\
\hline $\mathrm{wp}_{1}$ & $\begin{array}{l}\text { Darra-e- } \\
\text { Dokani1 }\end{array}$ & $\begin{array}{l}\text { Mountainous region, located at } \\
\text { the end of Dokani valley close } \\
\text { to Baba Mountain ridge }\end{array}$ & 67.84 & 34.71 & 2939 \\
\hline $\mathrm{wp}_{2}$ & $\begin{array}{l}\text { Darra-e- } \\
\text { Dokani } 2\end{array}$ & $\begin{array}{l}\text { Mountainous region, located at } \\
\text { the end of Dokani valley close } \\
\text { to Baba Mountain ridge }\end{array}$ & 67.83 & 34.71 & 2945 \\
\hline $\mathrm{wp}_{3}$ & $\begin{array}{c}\text { Syalayag } \\
\text { Foladi1 }\end{array}$ & $\begin{array}{c}\text { Located at the end and right } \\
\text { side of Foladi valley, near Baba } \\
\text { Mountain ridge, southwestern } \\
\text { part of Bamyan City }\end{array}$ & 67.709 & 34.777 & 3530 \\
\hline $\mathrm{wp}_{4}$ & $\begin{array}{c}\text { Syalayag } \\
\text { Foladi } 2\end{array}$ & $\begin{array}{c}\text { Located at the end and right } \\
\text { side of Floadi valley, near Baba } \\
\text { Mountain ridge, southwestern } \\
\text { part of Bamyan City }\end{array}$ & 67.701 & 34.775 & 3537 \\
\hline
\end{tabular}


Table 1. Cont.

\begin{tabular}{|c|c|c|c|c|c|}
\hline \multirow[t]{2}{*}{ Symbol } & \multirow[t]{2}{*}{ Location } & \multirow[t]{2}{*}{ Description of Location } & \multicolumn{2}{|c|}{$\begin{array}{l}\text { Coordinates } \\
\text { (WGS1984) }\end{array}$} & \multirow{2}{*}{$\begin{array}{c}\text { Elevation } \\
\text { (m) }\end{array}$} \\
\hline & & & Longitude & Latitude & \\
\hline $\mathrm{wp}_{5}$ & $\begin{array}{c}\text { Azdar } \\
\text { Shahidan }\end{array}$ & $\begin{array}{l}\text { Located in the Shahidan area, } \\
\text { left side of Bamyan-Yakawlang } \\
\text { main road with travertine and } \\
\text { limestone sediments }\end{array}$ & 67.57 & 34.80 & 3068 \\
\hline $\mathrm{wp}_{6}$ & Khoja Ali & $\begin{array}{l}\text { Located near the southern } \\
\text { entrance gate of Bamyan City, at } \\
\text { contact of sedimentary and } \\
\text { igneous rocks }\end{array}$ & 67.72 & 34.86 & 2635 \\
\hline $\mathrm{wp}_{7}$ & $\begin{array}{l}\text { Asidar } \\
\text { Bamyan }\end{array}$ & $\begin{array}{l}\text { Located at the end of Azhdar } \\
\text { valley, south of Bamyan City } \\
\text { with travertine and limestone }\end{array}$ & 67.75 & 34.85 & 2729 \\
\hline $\mathrm{wp}_{8}$ & $\begin{array}{l}\text { Paymory } \\
\text { Kalo1 }\end{array}$ & $\begin{array}{l}\text { Located at the right side of } \\
\text { Kabul-Bamyan highway, } \\
\text { middle point of Kalu valley, } \\
\text { eastern part of Bamyan City }\end{array}$ & 67.05 & 34.79 & 2505 \\
\hline $\mathrm{wp}_{9}$ & $\begin{array}{l}\text { Paymory } \\
\text { Kalo2 }\end{array}$ & $\begin{array}{l}\text { Located at the lift side of } \\
\text { Kabul-Bamyan highway, } \\
\text { middle point of Kalu valley, } \\
\text { eastern part of Bamyan City }\end{array}$ & 68.007 & 34.767 & 2504 \\
\hline $\mathrm{wp}_{10}$ & $\begin{array}{l}\text { Paymory } \\
\text { Kalo } 3\end{array}$ & $\begin{array}{l}\text { Located at the lift side of } \\
\text { Kabul-Bamyan highway, } \\
\text { middle point of Kalu valley, } \\
\text { eastern part of Bamyan City }\end{array}$ & 68.006 & 34.768 & 2502 \\
\hline $\mathrm{wp}_{11}$ & $\begin{array}{l}\text { Paymory } \\
\text { Kalo } 4\end{array}$ & $\begin{array}{l}\text { Located at the lift side of } \\
\text { Kabul-Bamyan highway, } \\
\text { middle point of Kalu valley, } \\
\text { eastern part of Bamyan City }\end{array}$ & 68.007 & 34.77 & 2502 \\
\hline $\mathrm{wp}_{12}$ & $\begin{array}{c}\text { Dahana } \\
\text { Ahangaran }\end{array}$ & $\begin{array}{l}\text { Located at the beginning of } \\
\text { Ahangaran valley, northeastern } \\
\text { part of Bamyan City }\end{array}$ & 67.92 & 34.81 & 2431 \\
\hline $\mathrm{wp}_{13}$ & Shash Pul & $\begin{array}{l}\text { Located at Shash Pol area, } \\
\text { norteastern part of Bamyan City }\end{array}$ & 67.45 & 34.51 & 2361 \\
\hline
\end{tabular}

\subsection{Water Sampling and Field Parameter Measurements}

The geographical location and elevation of every observation point (sampling point) were recorded by a handheld global positioning system (GPS) and the results were plotted in the maps (Figures 1 and 2) by the use of the WGS1984 geographic coordinate system. Further, in autumn (October-December 2018), water samples were collected from every study site into a $1000 \mathrm{~mL}$ sterile and dried glass bottles for the purpose of analyzing the essential trace elements and arsenic. A cool bag equipped with ice bags was used to keep the water samples stable, to prevent any possible chemical characteristic changes of the water samples, and to keep the water temperature at $4{ }^{\circ} \mathrm{C}$ until the laboratory analysis could be completed. During the sampling, some physicochemical parameters, including the $\mathrm{pH}$, temperature $\left({ }^{\circ} \mathrm{C}\right)$, electrical conductivity $(\mathrm{mS} / \mathrm{cm})$, and total dissolved solids (TDS) $(\mathrm{mg} / \mathrm{L})$, were measured directly in situ using a portable multimeter DR 2800 Spectrophotometer (manufacturer Hatch, Colorado, USA) with two probes for $\mathrm{pH}$ and EC.

\subsection{Water Analysis Methods}

All targeted essential trace elements and arsenic were analyzed at Green Tech water laboratory in Kabul city. Arsenic was analyzed with an EZ Arsenic Test Laboratory Kit. These kits indicate the linear range of As analysis, which were previously immobilized with the detector as 10-250 $\mu \mathrm{g} / \mathrm{L}$ of arsenic. The amount of barium was measured by $\mathrm{HACH}$ model 8014, copper with $\mathrm{HACH} 8026$, iron with $\mathrm{HACH} 8008$, manganese with 
HACH 8149, and zinc with HACH 8009 (Table 2). DR 3900 Laboratory Spectrophotometer for water analysis (manufacturer Hatch, Colorado, USA) was applied. All these methods of $\mathrm{HACH}$ for the purpose of water and wastewater analysis have been reviewed, approved, and accepted by the US Environmental Protection Agency (USEPA) to monitor regulatory requirements. For greater accuracy and to ensure the accuracy of the lab chemical analysis, a duplicate analysis was conducted and the physicochemical parameters were measured again in the lab and compared with the field values.

Table 2. Summary of methods utilized in laboratory analysis.

\begin{tabular}{|c|c|c|c|c|}
\hline \multicolumn{5}{|c|}{ Physical Tests } \\
\hline Tests & Unit & Methods & ${ }^{*}$ MCL as per USEPA & ${ }^{*} \mathrm{MCL}$ as per WHO \\
\hline $\mathrm{pH}$ & $($ ) & HACH \#8156 & $6.5-8.5$ & $6.5-8.5$ \\
\hline Color & $(\mathrm{CoPt})$ & HACH \#8125 & 15 & 15 \\
\hline Conductivity & $(\mu \mathrm{S} / \mathrm{cm})$ & HACH \#8160 & - & - \\
\hline Resistivity & $(\Omega . c m)$ & HACH-HQ Direct measurement & - & - \\
\hline Salinity & $(\%)$ & HACH-HQ Direct measurement & - & - \\
\hline Turbidity & (NTU) & HACH \#8237 & 5 & 5 \\
\hline TDS & $(\mathrm{mg} / \mathrm{L})$ & HACH-HQ Direct measurement & 500 & 1000 \\
\hline \multicolumn{5}{|c|}{ Chemical Tests } \\
\hline Arsenic & $(\mu \mathrm{g} / \mathrm{L})$ & EZ Arsenic Test Kit & 50 & 10 \\
\hline Barium & $(\mathrm{mg} / \mathrm{L})$ & НАCH \#8014 & 2 & 0.7 \\
\hline Chloride & $(\mathrm{mg} / \mathrm{L})$ & HACH \#8206 & 250 & 250 \\
\hline Cyanide & $(\mathrm{mg} / \mathrm{L})$ & НАСН\# 8027 & 0.2 & 0.1 \\
\hline Copper & $(\mathrm{mg} / \mathrm{L})$ & HACH \#8026 & 1.3 & 2 \\
\hline Hardness & $\left(\mathrm{mg} / \mathrm{Las} \mathrm{CaCO}_{3}\right)$ & HACH \#8329 & 500 & 500 \\
\hline Iron & $(\mathrm{mg} / \mathrm{L})$ & HACH \#8008 & 0.3 & 0.3 \\
\hline Manganese & $(\mathrm{mg} / \mathrm{L})$ & HACH \#8149 & 0.05 & 0.1 \\
\hline Nitrite & $(\mathrm{mg} / \mathrm{L})$ & НACH \#8507 & 1 & 3 \\
\hline Nitrate & $(\mathrm{mg} / \mathrm{L})$ & HACH \#8039 & 10 & 10 \\
\hline Phosphate & $(\mathrm{mg} / \mathrm{L})$ & HACH \#8048 & - & - \\
\hline Sulfate & $(\mathrm{mg} / \mathrm{L})$ & HACH \#8051 & 250 & 400 \\
\hline Zinc & $(\mathrm{mg} / \mathrm{L})$ & НACH \#8009 & 5 & 3 \\
\hline
\end{tabular}

* MCL: Maximum contamination level for drinking purposes. TDS: Total dissolved solids. - No limit recommended.

\subsection{Water Type Determination}

The water quality index $(W Q I)$ is an index reflecting the composite impacts of parameters to determine the water type and assess the health risk rate of the thermal springs.

WHO guidelines were used for the WQI calculations. The number of parameters were selected, then the relative weight $(\mathrm{Wi})$ of the selected parameters was calculated by this equation [36]:

$$
W_{i}=\frac{w_{i}}{\sum_{i=1}^{n} w_{i}}
$$

where $W_{i}$ means the relative weight, $w_{i}$ shows the weight of every parameter, and $i$ is equal to the number of parameters.

After that, the quality rating scale $\left(q_{i}\right)$ was determined for every parameter [36]:

$$
q_{i}=\left(\frac{C_{i}}{S_{i}}\right) \times 100
$$

where $q_{i}$ shows the quality rating according of $i$ th parameter concentration, and $n$ is a chemical parameter number, $C_{i}$ is the concentration of every parameter of each water sample $(\mathrm{mg} / \mathrm{L})$, and $S_{i}$ is the WHO standard value of the parameter.

Afterward, the sub index $\left(S I_{i}\right)$ of each parameter and $W Q I$ was calculated as by applying these equations [36]:

$$
S I_{i}=W_{i} \times q_{i}
$$




$$
W Q I=\sum S I_{i-n}
$$

Based on WQI, water has an excellent quality if the WQI ranges from 0 to 25 . Water is considered good quality if the WQI range is from 25 to 50 . Water of poor quality has a WQI range from 50 to 75 . Water is very poor quality if the WQI ranges from 75 to 100 . Water that is unsuitable for human consumption has a WQI number greater than 100 [36].

\section{Results}

\subsection{Physical Parameters of Thermal Springs}

The physical parameters of thermal springs are shown in Table 3. The temperature values ranged from $16{ }^{\circ} \mathrm{C}$ in Azhdar spring ( $\left.\mathrm{wp}_{7}\right)$ to $32{ }^{\circ} \mathrm{C}$ in the Paymory (Figure 1) system of thermal springs $\left(\mathrm{wp}_{8}-\mathrm{wp}_{11}\right)$, with an average of $25.4^{\circ} \mathrm{C}$. The $\mathrm{pH}$ ranged from 6.39 to 7.24 (average: 6.57 ), which shows all the thermal springs are slightly acidic. The amount of electrical conductivity varied substantially and ranged from 719 to $9150 \mu \mathrm{S} / \mathrm{cm}$ (average: $5713 \mu \mathrm{S} / \mathrm{cm}$ ), which is due to the high number of ions (cations and anions) existing in the thermal springs. Almost all of the studied thermal springs except the Khaja Ali ( $\left.w_{6}: 3 \mathrm{CoPt}\right)$ and Azhdar $\left(\mathrm{wp}_{7}: 14 \mathrm{CoPt}\right)$ thermal springs were colorful and this varied considerably between 3 and $133 \mathrm{CoPt}$ (average: $74.5 \mathrm{CoPt}$ ). Measurement of resistivity ranged from 109.3 to $1392 \Omega . \mathrm{cm}$. In regard to turbidity, almost all the thermal springs had extremely high turbidity and the value of this parameter changed from 0.21 to $57 \mathrm{NTU}$ (average: $37.4 \mathrm{NTU}$ ). The $\mathrm{wp}_{6}$ in Khaja Ali thermal spring was the only study point which showed a lower TDS value ( $351 \mathrm{mg} / \mathrm{L})$ than the WHO value $(1000 \mathrm{mg} / \mathrm{L})$. However, all the other springs contained extremely high TDS which ranged from 1471 to $4960 \mathrm{mg} / \mathrm{L}$ (Table 3).

Table 3. Physical properties of thermal springs.

\begin{tabular}{|c|c|c|c|c|c|c|c|}
\hline Study Points & Temperature & $\mathrm{pH}$ & Color & Conductivity & Resistivity & Turbidity & TDS \\
\hline & $\left({ }^{\circ} \mathrm{C}\right)$ & $(* \mathrm{SU})$ & $(\mathrm{CoPt})$ & $(\mu \mathrm{S} / \mathrm{cm})$ & $(\Omega . c m)$ & (NTU) & $(\mathrm{mg} / \mathrm{L})$ \\
\hline $\mathrm{wp}_{1}$ & 25 & 6.68 & 27 & 3630 & 276 & 46 & 1876 \\
\hline$w_{2}$ & 25 & 6.8 & 30 & 3720 & 260 & 40 & 1923 \\
\hline $\mathrm{wp}_{3}$ & 25 & 6.7 & 43 & 3123 & 290 & 50 & 1526 \\
\hline $\mathrm{wp}_{4}$ & 24 & 6.5 & 46 & 3000 & 305 & 52 & 1534 \\
\hline $\mathrm{wp}_{5}$ & 24 & 6.43 & 51 & 2900 & 349 & 57 & 1471 \\
\hline $\mathrm{wp}_{6}$ & 23 & 7.24 & 3 & 719 & 1392 & 0.21 & 351 \\
\hline $\mathrm{wp}_{7}$ & 16 & 6.46 & 14 & 6590 & 151.7 & 0.44 & 3530 \\
\hline $\mathrm{wp}_{8}$ & 32 & 6.41 & 120 & 8310 & 120.4 & 41.6 & 4490 \\
\hline$w^{10}$ & 31 & 6.39 & 125 & 8354 & 121.1 & 42.5 & 4502 \\
\hline $\mathrm{wp}_{10}$ & 31 & 6.44 & 129 & 8363 & 125 & 43.3 & 4512 \\
\hline $\mathrm{wp}_{11}$ & 32 & 6.56 & 117 & 8213 & 118.9 & 40.5 & 4456 \\
\hline $\mathrm{wp}_{12}$ & 20 & 6.39 & 133 & 9150 & 109.3 & 34 & 4960 \\
\hline $\mathrm{wp}_{13}$ & 23 & 6.4 & 130 & 8205 & 134 & 38.6 & 4687 \\
\hline
\end{tabular}

* Standard Unit.

\subsection{Hydrochemistry of Thermal Springs}

\subsubsection{Major Ions}

The results of the hydrochemistry analysis of the thermal springs are given in Table 4 . The chloride $\left(\mathrm{Cl}^{-}\right)$amount in these thermal springs changed from $49 \mathrm{mg} / \mathrm{L}$ in $\mathrm{wp}_{6}$ to $1630 \mathrm{mg} / \mathrm{L}$ in $\mathrm{wp}_{12}$ (Figure 3f) with an average of $795 \mathrm{mg} / \mathrm{L}$, and all the thermal springs, except for Khaja Ali thermal spring $\left(\mathrm{wp}_{6}\right)$, contained concentrations of chloride that are significantly higher than acceptable USEPA and WHO values $(250 \mathrm{mg} / \mathrm{L})$. The amount of cyanide in the thermal springs ranged from 0.004 to $0.022 \mathrm{mg} / \mathrm{L}$ (average: $0.014 \mathrm{mg} / \mathrm{L}$ ). The hardness rate of the thermal spring water, as assessed as $\mathrm{CaCO}_{3}$, was found to be in the range of 284 to $2804 \mathrm{mg} / \mathrm{L}$ (average: $1855 \mathrm{mg} / \mathrm{L}$ ). The result of thermal spring hardness compared to USEPA and WHO (2011) values (Table 4) illustrates that only water of the Khaja Ali thermal spring $\left(w_{6}\right)$ is soft, while all the others are extremely hard. This high 
value of hardness in thermal springs of central Bamyan is due to the widespread existence of sandstone and limestone in this area and their easy dissolution into the thermal springs. The amounts of nitrite and nitrate changed from 0.06 to $1.15 \mathrm{mg} / \mathrm{L}$ (average: $0.49 \mathrm{mg} / \mathrm{L}$ ) and 1.3 to $21 \mathrm{mg} / \mathrm{L}$ (average: $8.93 \mathrm{mg} / \mathrm{L}$ ), respectively. The amount of phosphate fluctuated from 0.08 to $0.65 \mathrm{mg} / \mathrm{L}$, and the values of sulfate ranged from 64 to $1430 \mathrm{mg} / \mathrm{L}$ (average: $861.7 \mathrm{mg} / \mathrm{L}$ ). The amount of sulfate in the thermal springs were potentially high in comparison with the values of the USEPA and WHO standards (Table 4).

Table 4. Hydrochemistry and trace elements of thermal springs.

\begin{tabular}{|c|c|c|c|c|c|c|c|c|c|c|c|c|c|}
\hline \multirow[t]{2}{*}{ Symbol } & Chloride & Cyanide & $\begin{array}{l}\text { Hardness } \\
(\text { as } \\
\left.\mathrm{CaCO}_{3}\right)\end{array}$ & Nitrite & Nitrate & Phosphate & Sulfate & $\begin{array}{l}\text { Arsenic } \\
\text { (As) }\end{array}$ & $\begin{array}{c}\text { Barium } \\
\text { (Ba) }\end{array}$ & $\begin{array}{l}\text { Copper } \\
\text { (Cu) }\end{array}$ & $\begin{array}{l}\text { Iron } \\
(\mathrm{Fe})\end{array}$ & $\begin{array}{c}\text { Manga- } \\
\text { nese } \\
\text { (Mn) }\end{array}$ & \multirow[t]{2}{*}{$\begin{array}{l}\text { Zinc } \\
\text { (Zn) }\end{array}$} \\
\hline & & & & $(\mathrm{mg} / \mathrm{L})$ & & & & $(\mu \mathrm{g} / \mathrm{L})$ & & & (mg/L) & & \\
\hline $\mathrm{Wp}_{1}$ & 365 & 0.01 & 1260 & 0.013 & 2.5 & 0.35 & 488 & 0 & 2 & 6.84 & 0.27 & 0.97 & 0.56 \\
\hline $\mathrm{wp}_{2}$ & 378 & 0.02 & 1287 & 0.02 & 3.1 & 0.65 & 502 & 0 & 2 & 6.65 & 0.25 & 0.92 & 0.63 \\
\hline $\mathrm{wp}_{3}$ & 283 & 0.01 & 1011 & 0.02 & 2.7 & 0.15 & 310 & 10 & 2 & 7.3 & 1.1 & 0.72 & 0.55 \\
\hline $\mathrm{wp}_{4}$ & 272 & 0.01 & 994 & 0.02 & 2.82 & 0.13 & 298 & 10 & 2 & 7.8 & 1.13 & 0.79 & 0.61 \\
\hline$w p_{5}$ & 262 & 0.009 & 982 & 0.02 & 3.1 & 0.19 & 340 & 10 & 2 & 9.02 & 1.8 & 0.88 & 0.5 \\
\hline $\mathrm{wp}_{6}$ & 49 & 0.004 & 284 & 0.01 & 1.8 & 0.12 & 64 & 0 & 1 & 0.11 & 0.08 & 0.017 & 0.23 \\
\hline $\begin{array}{l}w_{7} \\
w_{7}\end{array}$ & 590 & 0.006 & 2340 & 0.006 & 1.3 & 0.08 & 870 & 0 & 4 & 5.14 & 0.1 & 2.7 & 0.95 \\
\hline $\mathrm{wp}_{8}$ & 1280 & 0.022 & 2615 & 1.11 & 17 & 0.48 & 1370 & 100 & 6 & 6.04 & 3.49 & 2.88 & 0.82 \\
\hline$w^{1}$ & 1297 & 0.02 & 2722 & 1.13 & 19 & 0.52 & 1392 & 100 & 6.2 & 6.12 & 3.55 & 2.94 & 0.89 \\
\hline $\mathrm{wp}_{10}$ & 1303 & 0.02 & 2781 & 1.15 & 21 & 0.61 & 1401 & 100 & 6.5 & 6.27 & 3.89 & 3.01 & 0.94 \\
\hline $\mathrm{wp}_{11}$ & 1286 & 0.021 & 2804 & 1.12 & 19.4 & 0.55 & 1362 & 10 & 6.1 & 5.77 & 3.25 & 2.67 & 0.76 \\
\hline $\mathrm{wp}_{12}$ & 1630 & 0.013 & 2490 & 0.79 & 9.8 & 0.23 & 1430 & 0 & 7 & 5.66 & 2.11 & 1.9 & 1.18 \\
\hline $\mathrm{wp}_{13}$ & 1346 & 0.02 & 2549 & 0.97 & 12.6 & 0.34 & 1375 & 0 & 7 & 5.9 & 3.73 & 2.54 & 0.94 \\
\hline USEPA & 250 & 0.2 & 500 & 1 & 10 & - & 250 & 10 & 0.7 & $1-2$ & 0.3 & 0.1 & 3 \\
\hline WHO & 250 & 0.1 & 500 & 3 & 10 & 0.70 & 400 & 10 & 0.7 & $1-2$ & 0.3 & 0.1 & 3 \\
\hline
\end{tabular}

- Not given.
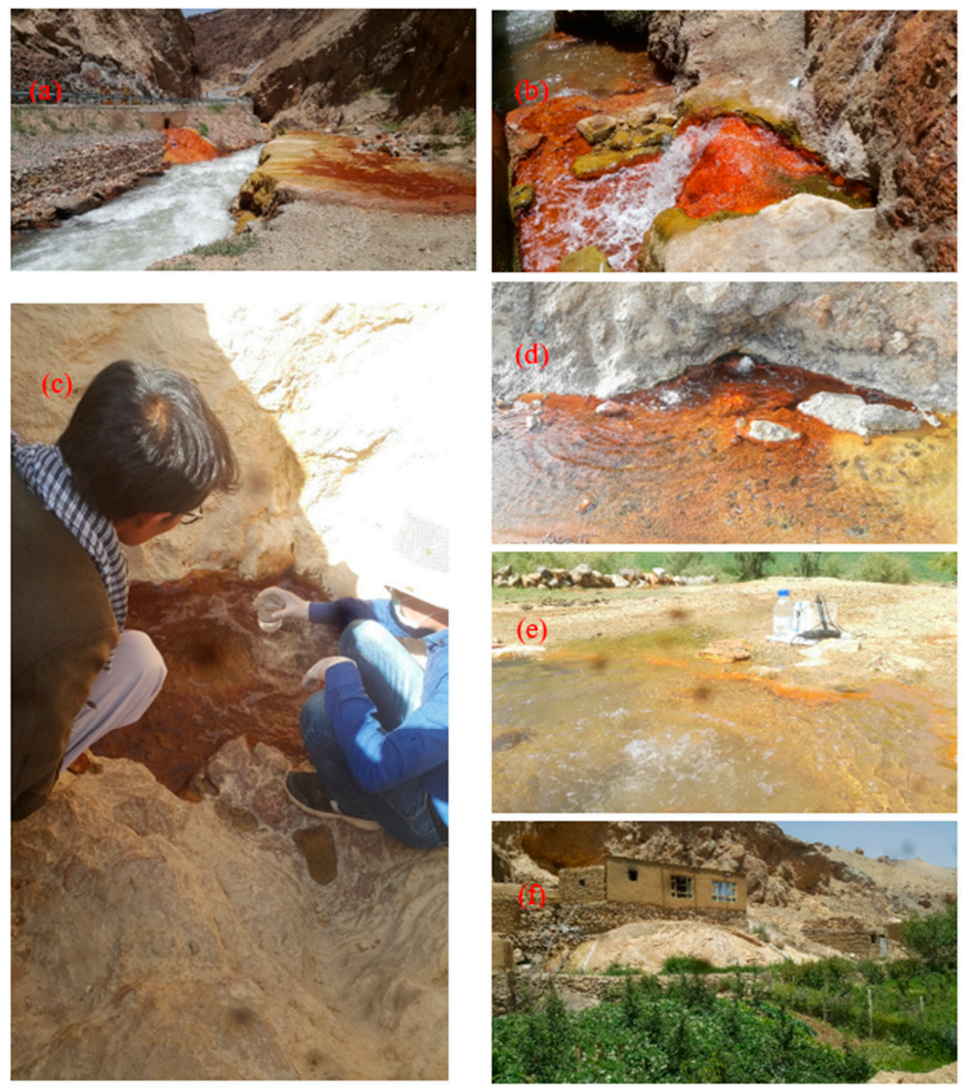

Figure 3. Photographs of some thermal springs: (a) range of thermal springs in Kalu valley, (b) Kalu main thermal spring, (c) Shahidan thermal spring, (d) Shash pul thermal spring, (e) Dokani first thermal spring, and (f) Darra Ahangaran thermal spring. 


\subsubsection{Trace Element Concentrations}

Five trace elements, including arsenic, were assessed in the thermal springs and the results are given in Table 4. Just over half of the thermal springs contained arsenic. The amount of arsenic in the first group, located in the northwestern part of the study area, was $10 \mu \mathrm{g} / \mathrm{L}$, which is equal to the maximum value of arsenic suggested by the WHO (Table 4); this included the $w_{3}, w p_{4}$, and $w p_{5}$ (Figure $3 c$ ) study points (Figure 1). However, the value of arsenic in the second group of thermal springs, situated in the eastern part of the study area (Figure 1 ) and included $\mathrm{wp}_{8}, \mathrm{wp}_{9}$, and $\mathrm{wp}_{10}$, were recorded at $100 \mu \mathrm{g} / \mathrm{L}$. This amount is high compared with the accepted WHO standard amount. The high amount of arsenic in the second part of the thermal springs is potentially related to the geological singularities of the spring locations. The thermal spring range in the Kalu valley (including $\left.w p_{8}-w p_{11}\right)$ flows through Paleoproterozoic-geological-age gneisses bedrock, which are the oldest rocks in Bamyan valley and partly covered by sandstone. This is the reason why the thermal spring contains arsenic and trace elements. The second range of thermal springs with a concentration of $10 \mu \mathrm{g} / \mathrm{L}$ of arsenic (including $\mathrm{wp}_{3}, \mathrm{wp}_{4}$, and $\mathrm{wp}_{5}$ ) flows through Pliocene-geological-age conglomerate and sandstone-based rocks, which cover the older bedrock. The high arsenic concentration in the thermal spring originates from these bedrocks.

The amount of barium fluctuated significantly and ranged from 1 to $7 \mathrm{mg} / \mathrm{L}$, with an average of $4.14 \mathrm{mg} / \mathrm{L}$ (Figures 4 and 5), which is significantly higher than $0.7 \mathrm{mg} / \mathrm{L}$, which is suggested in the WHO standard (Figure 6). Copper and total iron are present in the range of $0.11-9.02 \mathrm{mg} / \mathrm{L}$ (average: $6.05 \mathrm{mg} / \mathrm{L}$ ) and $0.08-3.89 \mathrm{mg} / \mathrm{L}$ (average: $1.90 \mathrm{mg} / \mathrm{L}$ ), respectively (Figures 4 and 5).

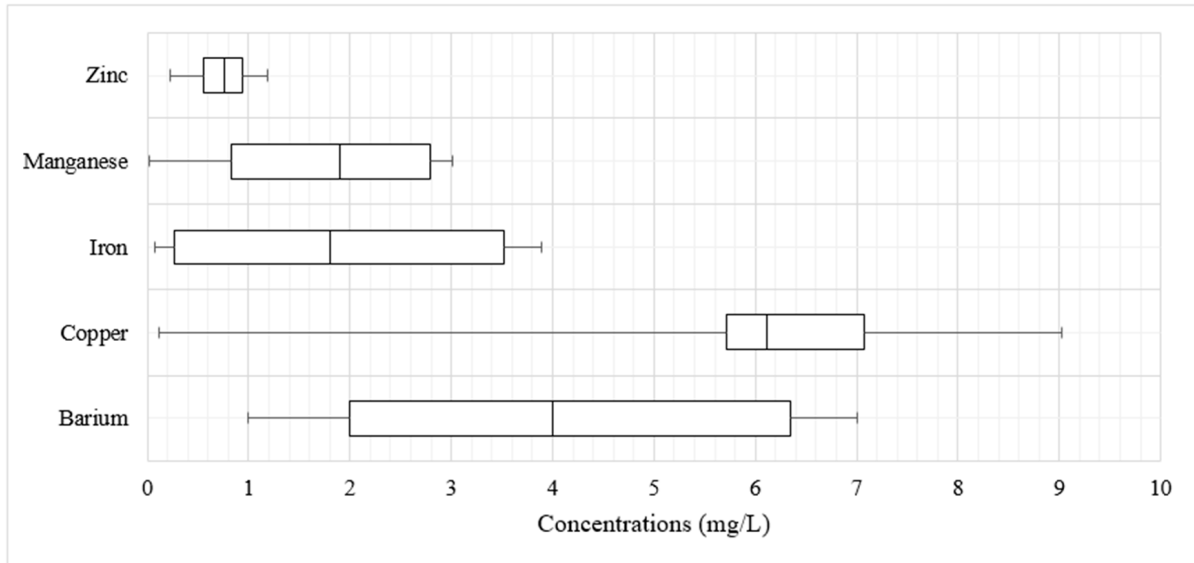

Figure 4. Boxplot of trace elements in thermal springs.

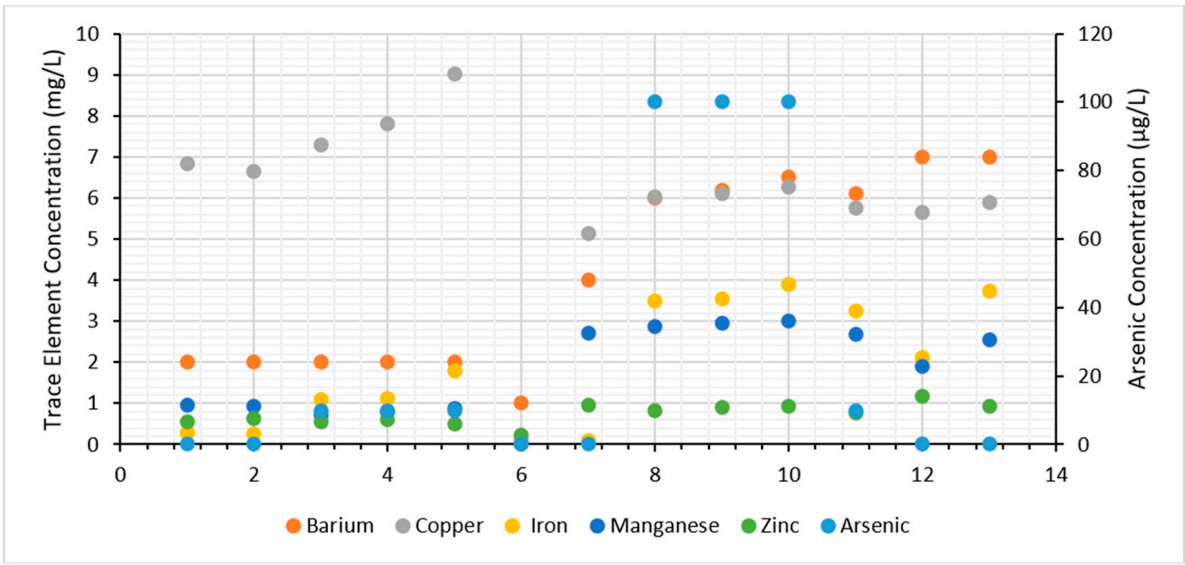

Figure 5. Concentrations of trace elements in thermal springs. 

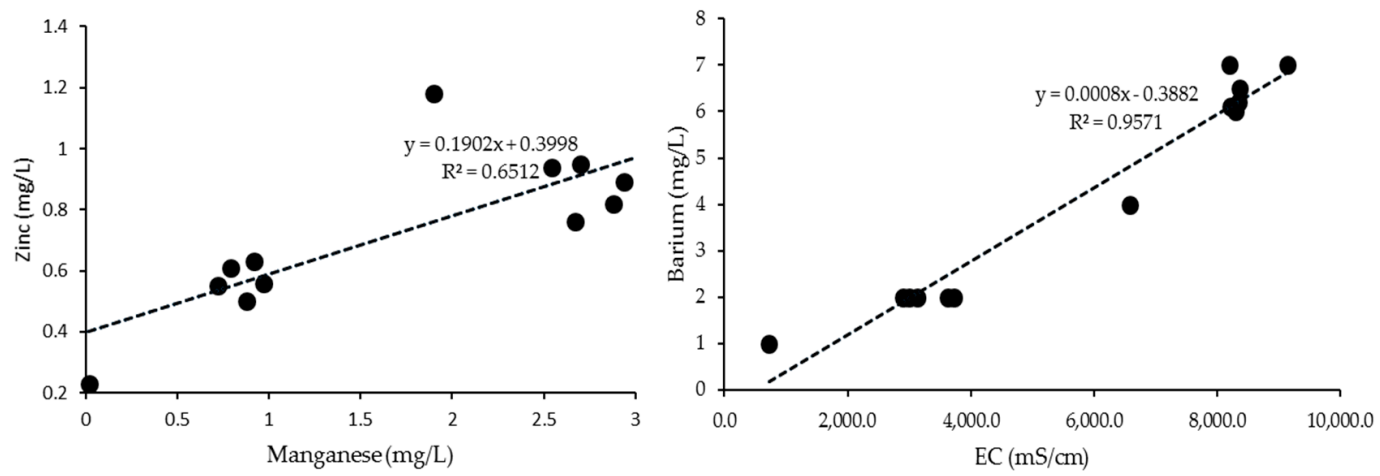

Figure 6. The strongest correlation between some parameters.

The concentration of manganese varied from 0.017 to $3.01 \mathrm{mg} / \mathrm{L}$, with an average value of $1.76 \mathrm{mg} / \mathrm{L}$, whereas zinc ranged from 0.23 to $1.18 \mathrm{mg} / \mathrm{L}$ (average: $0.74 \mathrm{mg} / \mathrm{L}$ ) (see Figure 4).

\subsection{Correlations}

The study of the correlation coefficient between two variables is a way to determine the sufficiency of the first variable for the prediction of the second one [37]. This coefficient is utilized for the assessment of the correlation between the variables if the dependent variable is just influenced through the independent variable and vice versa [37].

The selection of variables was based on the physicochemical properties and the measured trace elements' importance with related correlation and determination of the variables' dependency for the trace elements (see Table 5). The results show a strong correlation $(r>0.9)$ and a good correlation $(r=<0.9$ to $>0.5)$. The strongest correlations are recognized between electrical conductivity and total dissolved solids $(r=0.999)$, barium $(r=0.978)$ (see Figure 6), manganese $(r=0932)$, and zinc $(r=0.916)$, as well as between TDS and manganese $(r=0.930)$ and zinc $(r=0.913)$. Further, barium is strongly correlated with manganese $(r=0.892)$ and zinc $(r=0.871)$ and between manganese and zinc $(r=0.807)$ (see Table 5 and Figure 7$)$. The constituents originate from the same source, and the thermal springs have near equal origins. The trace elements were from the same geological settings, which are located at the thermal springs' pathway. These strong correlations between parameters represent the variables' dependency. Investigations of the geological setting and mineral composition of the bedrock are planned for future studies.

Table 5. Correlation between studied parameters of thermal springs.

\begin{tabular}{|c|c|c|c|c|c|c|c|c|c|c|}
\hline & PH & EC & Turbidity & TDS & Arsenic & Barium & Copper & Iron & Manganese & Zinc \\
\hline $\mathrm{PH}$ & 1 & & & & & & & & & \\
\hline EC & -0.73 & 1 & & & & & & & & \\
\hline Turbidity & -0.46 & 0.06 & 1 & & & & & & & \\
\hline TDS & -0.72 & 0.99 & 0.05 & 1 & & & & & & \\
\hline Arsenic & -0.38 & 0.49 & 0.22 & 0.48 & 1 & & & & & \\
\hline Barium & -0.68 & 0.97 & 0.06 & 0.98 & 0.49 & 1 & & & & \\
\hline Copper & -0.66 & 0.11 & 0.84 & 0.09 & 0.08 & 0.03 & 1 & & & \\
\hline Iron & -0.63 & 0.77 & 0.39 & 0.78 & 0.67 & 0.84 & 0.19 & 1 & & \\
\hline Manganese & -0.71 & 0.93 & -0.01 & 0.93 & 0.61 & 0.89 & 0.10 & 0.76 & 1 & \\
\hline Zinc & -0.78 & 0.92 & 0.03 & 0.91 & 0.31 & 0.87 & 0.21 & 0.56 & 0.81 & 1 \\
\hline
\end{tabular}



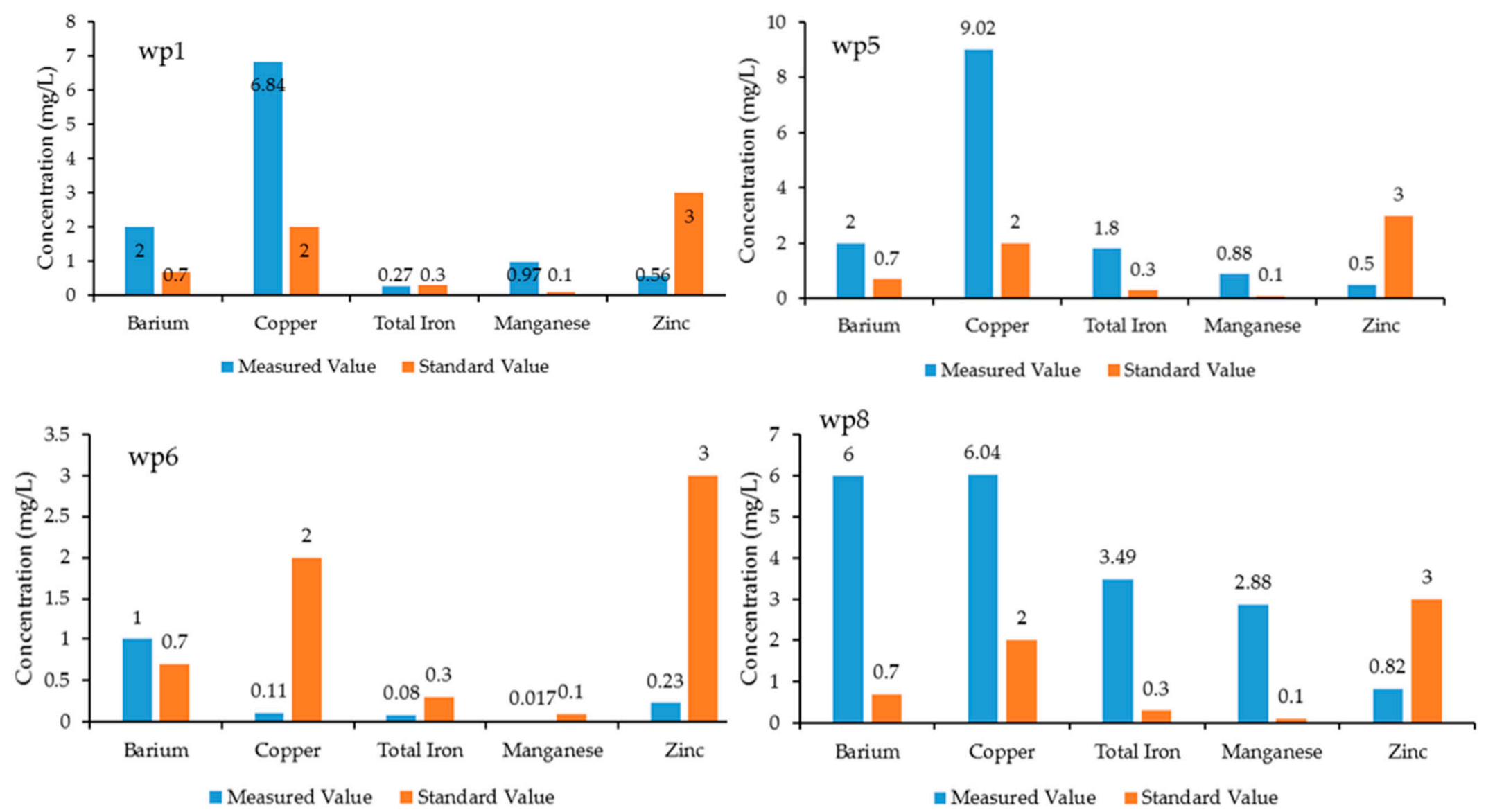

Figure 7. Compression of measured values of trace elements with standard WHO values. 


\subsection{Water Type and Health Risk Assessment}

In many parts of the study area, the thermal springs flow into the surface water, including rivers, and this water is directly used for drinking or irrigation purposes. The result outputs based on WQI were compiled in Figure 8. All the thermal springs water samples have high numbers, compared to the $\mathrm{WQI}=100$, maximum standard value for potable water. Only the Khaja Ali thermal spring (wp6 with WQI $=17$ ) is suitable for drinking purpose.

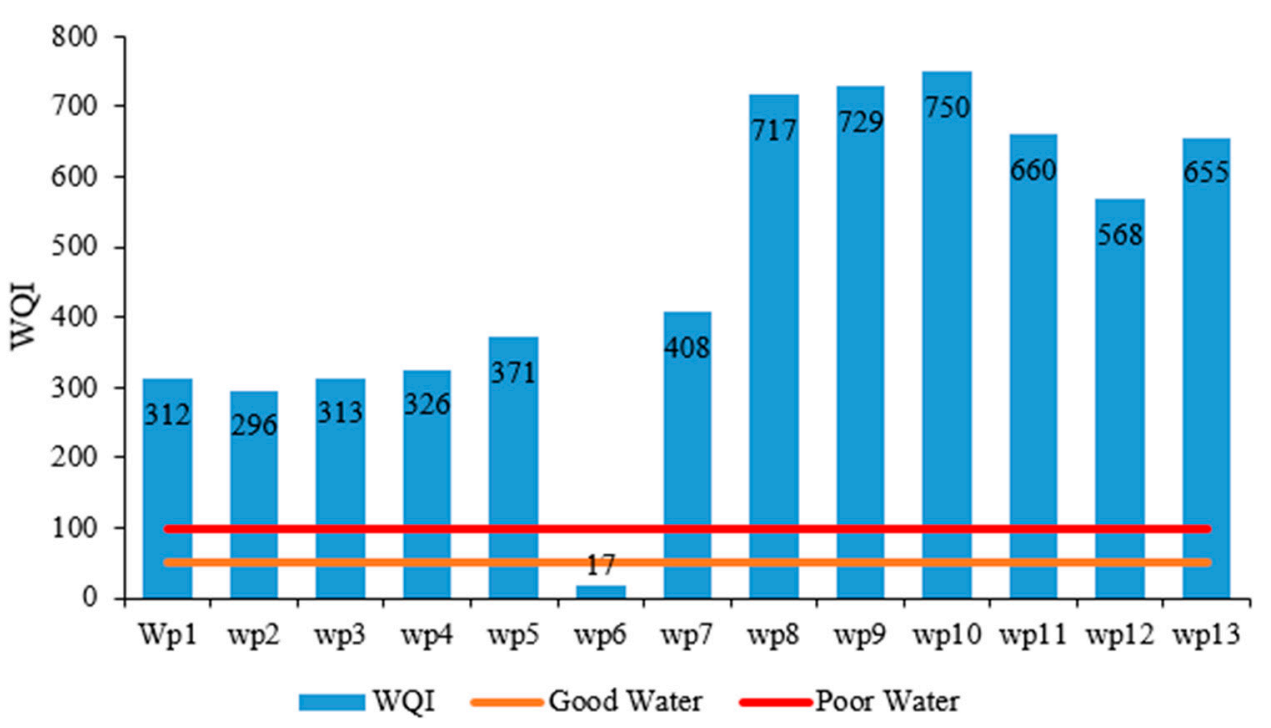

Figure 8. Determination of water type based on water quality index.

\section{Discussion}

Determination of the natural situation of the groundwater chemistry and water-rock interactions is one the of main aims of physicochemical studies [38-40]. Here, physical parameters such as temperature, $\mathrm{pH}$, color, conductivity, resistivity, salinity, turbidity, and TDS were measured in the study area. Almost all of the water of the thermal springs was from a yellowish to brownish color. The values of almost all the water at the study points were higher than the $\mathrm{WHO}$ value $(15 \mathrm{CoPt})$. However, the $\mathrm{pH}$ levels of all the thermal springs were in the standard range (6.5-8.5) and varied from 6.39 to 7.24. The amount of total dissolved solids (TDS) was extremely high $($ Max. $=4960 \mathrm{mg} / \mathrm{L}, \mathrm{Min} .=351 \mathrm{mg} / \mathrm{L}$, Average $=3063 \mathrm{mg} / \mathrm{L})$ compared with the WHO standard $(1000 \mathrm{mg} / \mathrm{L})$.

Arsenic concentrations in thermal water present values of one to three orders of magnitude higher compared with the cold groundwater [38]. Arsenic is introduced into the water via an accumulation of related deposits such as iron, sulfates, oxides, and hydroxides [41,42]. It can originate naturally and artificially: natural arsenic contamination can occur in different geological and climatic conditions [6]. The maximum amount of arsenic in the thermal springs of this study area was $100 \mu \mathrm{g} / \mathrm{L}$, which is significantly higher than the maximum value of $\mathrm{WHO}(10 \mu \mathrm{g} / \mathrm{L})$. In addition to arsenic, some other trace elements such as barium, copper, iron, manganese, and zinc were assessed in the thermal springs. The average amount of barium was $4.14 \mathrm{mg} / \mathrm{L}$, which is much higher than the $0.7 \mathrm{mg} / \mathrm{L}$ maximum value of WHO. Concentrations of copper, iron, manganese, and zinc averaged at $6.05,1.90,1.76$, and $0.74 \mathrm{mg} / \mathrm{L}$ respectively. Thus, the thermal water sources of central Bamyan are significantly contaminated with trace elements.

According to other research [37,43], water is considered to be of excellent quality if the $W Q I$ ranges from 0 to25, water is considered to be good quality if the WQI has a range from 25 to 50 , water has poor quality if the WQI is from 50 to 75 , water has very poor quality if WQI ranges from 75 to 100 , and water is unsuitable for drinking with a WQI greater than 
100. As mentioned above, all the thermal springs in this study, except $\left(\mathrm{wp}_{6}\right)$, are in very bad condition because the WQI values are much higher than 100 .

Overall, the thermal springs of central Bamyan that were studied are heavily contaminated with arsenic and some trace elements. Thus, this water poses a significant health risk if it is used for drinking and irrigation.

\section{Conclusions}

Thermal springs are natural phenomena with high concentrations of metals, including arsenic, as essential trace elements. Hence, it is imperative to determine the amount of these trace elements in thermal springs in order to protect public health. Originally, the majority of the thermal springs in central Bamyan were formed due to national and local tectonic activities except for the Khaja Ali thermal spring, which mainly originated from volcanic activities. This study found that some thermal springs located northeast of Bamyan City (in Kalu valley) have anomalously high concentrations of arsenic, copper, and barium. The amount of zinc in the thermal springs is significantly higher than acceptable standards. Electrical conductivity has a strong correlation with total dissolved solids, barium, manganese, and zinc, as well as barium with manganese. Based on the calculated values of the water quality index, water from all of these thermal springs are unsuitable for drinking except for the Khaja Ali thermal spring, which is of excellent quality. Thus, these sources of water should not be used for the purpose of drinking and irrigation.

Author Contributions: Conceptualization, methodology, H.A.J. and J.S.; software, H.A.J. and M.A.M.; validation, H.A.M., H.A.J., formal analysis, H.A.J. and J.S.; investigation, H.A.J., H.A.M., M.A.M.; data curation, H.A.J., J.S. and H.A.M.; writing-original draft preparation, H.A.J.; writingreview and editing, H.A.J., J.S., H.A.M. and M.A.M.; supervision, J.S., H.A.M., M.A.M. and H.A.J.; project administration, H.A.J., J.S., H.A.M., M.A.M. All authors have read and agreed to the published version of the manuscript.

Funding: The data used in this current paper was part of a research project which was supported by the University of Central Asia (UCA), the Institute of Mountain Research (MSRi); a research grant from IDRC (Canada); and the US National Academies of Sciences, Engineering, and Medicine (NAS) USAID Partnerships for Enhanced Engagement in Research (PEER) cycle 5 project Grant Award Number AID-OAA-A-11-00012.

Institutional Review Board Statement: Not applicable.

Informed Consent Statement: Not applicable.

Acknowledgments: This study was supported by the University of Central Asia (UCA), the Institute of Mountain Research (MSRi) and through a research grant from IDRC (Canada). The writers are thankful to the UCA staff, especially Aziz Ali Khan, for supporting and assisting us during the study. Some tests were conducted in the laboratory of the Soil Science Department, Faculty of Agriculture and we are grateful for their support. Further, the publication was supported by the Department of Civil and Environmental Engineering, School of Engineering and Digital Sciences, the Environment and Resource Efficiency Cluster (EREC) of Nazarbayev University, Kazakhstan, and the US National Academies of Sciences, Engineering, and Medicine (NAS) USAID Partnerships for Enhanced Engagement in Research (PEER) cycle 5 project Grant Award Number AID-OAA-A-1100012. Authors also acknowledge the anonymous reviewers whose valuable suggestions helped us in improving the quality of this paper.

Conflicts of Interest: The authors declare no conflict of interest.

\section{References}

1. Mahala, S.C. Geology, Chemistry and Genesis of Thermal Springs of Odisha, India; Springer: Cham, Switzerland, 2019. [CrossRef]

2. Dulanya, Z.; Morales-Simfors, N.; Sivertun, A. Comparative study of the silica and cation geothermometry of the Malawi hot springs: Potential alternative energy source. J. Afr. Earth Sci. 2010, 57, 321-327. [CrossRef]

3. Wada, O. What are trace elements? Their deficiency and excess states. Jpn. Med. Assoc. 2003, 129, 607-612. 
4. Munoz, M.; Bhattacharya, P.; Stacek, O.; Ramos, O.; Aguirre, J.; Bundschuh, J.; Maity, J. Arsenic and other trace elements in thermal springs and in cold waters from drinking water wells on the Bolivian Altiplano. J. South Am. Earth Sci. 2015, 60, 10-20. [CrossRef]

5. Liu, Y.; Hu, Z.; Gao, S.; Günther, D.; Xu, J.; Gao, C.; Chen, H. In situ analysis of major and trace elements of anhydrous minerals by LA-ICP-MS with applying an internal standard. Chem. Geol. 2008, 257, 34-43. [CrossRef]

6. Jones-Hughes, T.; Peters, J.; Whear, R.; Cooper, C.; Evans, H.; Depledge, M.; Pearson, M. Are interventions to reduce the impact of arsenic contamination of groundwater on human health in developinng countries affective? A systematic review. Environ. Evid. 2013, 2, 11. [CrossRef]

7. Johannesson, K.; Tang, J. Conservative behavior of arsenic and other oxyanion-forming trace elements in an axic groundwater flow system. J. Hydrol. 2009, 378, 13-28. [CrossRef]

8. Phan, K.; Phan, S.; Huoy, L.; Suy, B.; Wong, M.; Hashim, J.; Kim, K. Assessing mixed trace elements in groundwater and their health risk of residents living in the Mekong River basin of Cambodia. Environ. Pollut. 2013, 182, 111-119. [CrossRef] [PubMed]

9. Reimann, C.; Robert, G. Geochemical background- concept and reality. Sci. Total Environ. 2005, 350, 12-27. [CrossRef]

10. Das, D.; Chatterjee, A.; Mandal, B.K.; Samanta, G.; Chakraborti, D. Arsenic in groundwater in six district of West Bengal, India: The biggest arsenic calamity in the world: Part2. Arsenic concentration I drinking water, hair, nails, urine, skin scale and liver tissue (biopsy) of the affected people. Analyst 1995, 120, 917-924. [CrossRef]

11. Smith, A.H.; Lingas, E.O.; Rahman, M. Concentration of drinking water by arsenic in Bangladesh: A public health emergency. Bull. WHO 2000, 78, 1093-1101.

12. Tan, J. The Atlas of Endemic Diseases and Their Environments in the People's Republic of China; Science Press: Beijing, China, 1989.

13. Combs, G.F.; Welch, R.M.; Duxbury, J.M.; Uphoff, N.T.; Nesheim, M.C. Food-Based Approaches to Preventing Micronutrient Malnutrition: An International Research Agenda; Cornell University: Ithaca, NY, USA, 1996.

14. Vengosh, A.; Cahit, H.; Ismai, H.K. Geochemical constraints for the origen of thermal waters from western Turkey. Appl. Geochem. 2002, 18, 1117-1119. [CrossRef]

15. Binda, G.; Andrea, P.; Alessandro, M.M.; Paula, J.N.; Michael, R.R. Towards the understanding of hydrogeochemical seismic responses in karst aquifers: A retrospective meta-analysis focused on the apennines (Italy). Minerals 2020, 10, 1058. [CrossRef]

16. Tonani, F. Geochemical methods of exploration for geothermal energy. Geothermics 1970, 2, 492-515. [CrossRef]

17. White, D.E. Geochemistry applied to the discovery, evaluation, and exploration of geothermal energy resources. Geothermics 1970, $2,58-80$.

18. Fournier, R.O.; Truesdell, A.H. An empirical Na-K-Ca geothermometer for natural waters. Geochim. Cosmochim. Acta 1973, 37, 1255-1275. [CrossRef]

19. Ellis, A.J.; Mahon, W.A.J. Chemistry and Geothermal Systems; Academic Press: New York, NY, USA, 1977.

20. Fournier, R.O. A revised equation for Na-Kgeothermometer. Trans. Geotherm. Resour. Counc. 1979, 3, $221-224$.

21. Giggenbach, W.F.; Gonfiantini, R.; Jangi, B.L.; Truesdell, A.H. Isotopic and chemical composition of Parbati valley geothermal discharges, NW-Himalaya, India. Geothermics 1983, 12, 199-222. [CrossRef]

22. Giggenbach, W.F. Geothermal solute equilibria. Derivation of Na-K-Mg-Ca geoindicators. Geochim. Cosmochim. Acta 1988, 52, 2749-2765. [CrossRef]

23. King, M.; Sturtewagen, B. Making the Most of Afghanistan's River Basins: Opportunities for Regional Cooperation; EastWest Institute: New York, NY, USA, 2010.

24. Favre, R.; Kamal, G. Water Atlas of Afghanistan; FAO: Kabul, Afghanistan, 2004.

25. Tünnermeier, T.; Houben, G. Hydrogeology of the Kabul Basin, Part 1E2; BGR: Hannover, Germany, 2005.

26. Mack, T. Groundwater availability in the Kabul basin, Afghanistan. Groundw. South Asia 2018, 23-35. [CrossRef]

27. Mack, T.; Akbari, M.; Ashoor, M.; Chornack, M.; Coplen, T.; Emerson, D.; Verstraeten, I. Conceptual Model of Water Resources in the Kabul Basin, Afghanistan; U.S.Geological Survey: Reston, VA, USA, 2010.

28. Broshears, R.; Akbari, M.; Chornack, M.; Mueller, D.; Ruddy, B. Inventory of Groundwater Resources in the Kabul Basin, Afghanistan; U.S. Geological Survey: Reston, VA, USA, 2005.

29. Saba, D.; Najaf, M.E.; Musazai, A.; Taraki, S. Geothermal Energy in Afghanistan: Prospects and Potential; Center on International Cooperation: New York, NY, USA, 2004.

30. Abullah, S.; Chmyriov, V. Geology and Mineral Resources of Afghanistan; British Geological Survey: Amersham, UK, 2008.

31. Kyriazis, D.; Zagana, E.; Stamatis, G.; Fillippidis, F.; Psomiadis, E. Assessment of groundwater pollution in relation to heavy metals of the alluvial aquifer of Tn hriasion Plan (NW Attica). Bull. Geol. Soc. Greece 2013, 47, 731-739. [CrossRef]

32. Azimi, M. Geography of Bamyan Province (Physical, Human, Economical); Alhoda: Kabul, Afghanistan, 2012.

33. Aliyar, Q. Temperature change during three dicades in Central Bamyan. Acad. J. Bamyan Univ. 2019, 11, 1-9.

34. Cook, D. Bamyan Province Climatology and Temperature Extremes in Afghanistan; Defense Technology Agency: Kabul, Afghanistan, 2011.

35. USGS. Geological Map of Afghanistan; MicroImages: Lincoln, NE, USA, 2005.

36. Jawadi, H.A.; Jay, S.; Daniel, D.S. A detailed assessment of groundwater quality in the Kabul Basin, Afghanistan, and suitability for future development. Water 2020, 12, 2890. [CrossRef]

37. Batabyal, A.; Chakraborty, S. Hydrogeochemistry and water quality index in the assessment of groundwater quality for drinking use. Water Environ. Res. 2015, 607-619. [CrossRef] [PubMed] 
38. Ghoreyshinia, S.K.; Deshaee, A. Hydrogeochemistry, circulation path and arsenic distribution in Tahlab aquifer, East of Taftan Volcano, SE Iran. Appl. Geochem. 2020, 119. [CrossRef]

39. Lafta, J. Analysis of water quality using chemical-physical- biological paramters of the kinds fo water used for drinking in the Baghdad Province- Al Adhamiya city. Chem. Mater. Res. 2015, 7, 1-4.

40. Patil, P.; Sawant, D.; Deshmukh, R. Physico-chemical paramters for testing of water- A review. Int. J. Environ. Sci. 2012, 3, 1194-1207.

41. Schwenzer, S.; Tommaseo, C.; Kersten, M.; Kirnbauer, T. Speciation and oxidation kinetics of arsenic in the thermal springs of Wiesbade spa, Germany. Fresenius' J. Anal. Chem. 2001, 371, 927-933. [CrossRef]

42. Kikawada, Y.; Fuji, H.; Ohno, Y.; Oi, T. Mobility of arsenic in hot springs water accompanying its penetration into the ground. J. Radioanal. Nucl. Chem. 2008, 278, 323-326. [CrossRef]

43. Etim, E.; Odoh, R.; Itodo, A.; Umoh, S.; Lawal, U. Water quality index for the assessment of water quality from different sources in the Niger Delta region of Nigeria. Front. Sci. 2013, 3, 89-95. [CrossRef] 